\title{
The Green Economy as Sustainable Alternative?
}

Daniel M. Knight (University of St Andrews)

\begin{abstract}
This article explores the green economy as a sustainable alternative to austerity in Greece. I argue that the movement toward the green economy has been hijacked by multinational corporations taking advantage of austerity-era policy that encourages a repetition of the same neoliberal model of privatization, short-term accumulation, rentier agreements and resource extraction. This is contrary to views that cast 'crisis' as an incubator of economic strategies that may feed green ecological transformations of the economy leading, ultimately, to sustainable growth. Current configurations of advanced capitalist power enable and promote injurious 'green grabbing' in part by leveraging the fantasy of a green economy as a solution to the fiscal crisis. As an alternative to austerity the green economy requires further uncoupling from neoliberal business opportunism to allow natural capital to be harnessed as an economic asset for sustainable long-term public good.
\end{abstract}

\section{Bio}

Daniel M. Knight is a Lecturer in Social Anthropology and Leverhulme Fellow at the University of St Andrews, and Visiting Fellow at the Hellenic Observatory, London School of Economics and Political Science. He has published on economic crisis, time, temporality, historicity, neoliberalism, neocolonialism, and renewable energy initiatives. He is author of History, Time, and Economic Crisis in Central Greece (Palgrave, 2015), editor (with Charles Stewart) of Ethnographies of Austerity: Temporality, Crisis and Affect in Southern Europe (Routledge, 2017), and co-edits History and Anthropology journal.

\section{Address}

Department of Social Anthropology, University of St Andrews, 71 North Street, St Andrews, Fife, KY16 6AL, United Kingdom, dmk3@st-andrews.ac.uk 


\section{Introduction}

Sitting in the second row of the Sheikh Zayed Theatre at the London School of Economics and Political Science in March 2013 I was almost trembling with anticipation as Alexis Tsipras, then leader of the Greek opposition, took to the stage. A young scholar of Greece, I had just taken-up post at the LSE and this was the first political celebrity I had ever encountered; a man and a party sending shockwaves across Europe with a no-nonsense anti-austerity message who flatly refused to bow to international financial tutelage. Although the audience did not know it, this was the man who would sweep to a resounding electoral victory less than two years later when his SYRIZA party recorded just over 36 percent of the public vote, leaving the traditional parties of both Left and Right in ruins.

Entitled "Greece's Way Out of the Crisis", Tsipras' talk proposed that 'The policies of austerity that are being implemented in Europe, not only in the eurozone, but also here in the UK, do not appear to be providing a viable exit from the crisis'. He argued that reforming the European Central Bank, Eurobonds and fiscal transfers - potential solutions to economic crisis - is unlikely to happen without social mobilization. 'In the past, elites have never given up their power and privileges willingly. It is unlikely they will do so in the future. Only a democratic drive to change the balance of class forces within Europe can bring about a progressive exit', his abstract read.

After a speech delivered in English, the first question from the floor concerned how SYRIZA would invest in long-term sustainable energy and environmental development to create jobs in the green economy. Through a translator, Tsipras replied with a distinctly wry smile, "the truth is that from our side in Greece there is no discussion at all about effects on the environment because the situation is more important with what is happening with the people". ${ }^{i}$ He acknowledged the fear that seeking economic growth will have effects on the environment and that if he became Prime Minister he would implement a programme of sustainable development that would address the destruction of people's rights and environmental degradation. He mentioned that the cost of petrol for central heating had skyrocketed, meaning people now felt like they were "living in the 1950s", resorting to "burning anything they can find at hand which is causing huge problems for the environment in cities" (see Knight 2017).

Despite the future Prime Minister's contradictory response - at once denying that the environment was a core government or grassroots concern while citing increasing problems with heating provision - my own fieldwork found that in 2013 Greece the green economy was at the forefront of public debates on energy poverty, neo-colonial projects of resource extraction and dramatic environmental degradation. I had recently embarked on research funded by the National Bank of Greece (and later the Addison Wheeler Trust and Leverhulme Trust) on the social and ecological impact of renewable energy developments in central Greece as local people strived to pay suffocating new taxes, came to terms with unprecedented unemployment and discussed feelings of returning to an era of premodernity (Knight 2015a). Originally initiatives aimed at repaying national debt and decreasing fiscal deficit through energy export to northern Europe, from 2011 there has been a remarkable surge in photovoltaic (solar) parks placed on agricultural land in central Greece and wind farms constructed in the Aegean Islands. Renewable energy developments provide a stable monthly income for disenfranchised farmers through feed-in tariffs and 
have presented new employment opportunities for local mechanics and salespeople who have diversified into the green economy sector.

A few months after Tsipras' visit to London, I was contacted by a US think-tank requesting comment on a draft SYRIZA policy document placing sustainable development at the core of its plans for economic growth and emphasizing the roots of the SYRIZA movement in thematic social movements such as radical ecology. It is striking that since the onset of the global financial crisis, governments have scaled back their commitments to the green economy, overlooking the potential for economic growth through emerging ecologies of the socio-technical. Citing concerns of public funds, competitiveness and more pressing financial obligations, "green growth" has largely been abandoned in Western Europe. Yet, as Sean Sweeney (2015:1) of the Worker Institute at Cornell University has observed, austerity could potentially spur a fundamental departure from the slow and stuttering progress of environmental sustainability, offering opportunities for what SYRIZA has termed the 'ecological transformation of the economy' that can offer 'a contrast to capitalist competition, continuous enlargement and accumulation' reinstating 'the balance between human activities and natural resources ... which ensures sustainable growth'. ${ }^{i i}$ The ecological transformation of the economy can become a key element in a more just socio-political vision, as emergent ecologies of capital, technical solutions, and social arrangements find new and opportunistic possibilities in the wreckage of ongoing disasters, assisting imaginations beyond the apparent apocalypse of current crises (see Kirksey 2015). However, I argue that the movement toward the green economy as an alternative to austerity in Greece has been hijacked by multinational corporations taking advantage of austerity-era policy that encourages a repetition of the same neoliberal model of privatization, short-term accumulation, rentier agreements and resource extraction symptomatic of the relationship between the West and the new Global South (on the financialization of vital services see Muehlebach, this issue). It must be stated that the European Union-led drive for growth in the renewables sector has been supported by both the previous New Democracy and current SYRIZA-led coalition governments, as well as passively endorsed by many of my research participants who have knowingly invested in opportunistic programmes focused on short-term financial gains.

\section{From the Green Economy to Green Grabbing}

In many parts of the world, Fairhead, Leach and Scoones (2012:254) argue in their influential edited collection, "a new political economy of land and livelihoods is emerging, driven by 'green' market economics, and global discourses of the use and repair of ecosystems". In theory, the green economy aims to reduce environmental risks by promoting sustainable development within the parameters of the neoliberal market system by introducing accountability into the appropriation of nature. The notion that natural resources and ecological services possess inherent economic value may not, on the surface, seem to differ from previous regimes of resource extraction such as oil prospecting or stripmining. However, as defined by the United Nations Environment Program (UNEP, 2011) "to be green, an economy must not only be efficient, but also fair. Fairness implies recognizing global and country level equity dimensions, particularly in assuring a just transition to an economy that is low-carbon, resource efficient, and socially inclusive".iii Ideally, the green 
economy takes the relationship between the human and non-human world that is integral to the neoliberal project and reimagines corporate accountability to both society and nature. Maintaining a market-driven focus at the heart of environmental management and ecosystems services, the green economy champions "ecological modernization where economic growth and environmental conservation work in tandem" within a just social and ethical calculus (Fairhead et. al. 2012:240, see also Mol and Spaargarden 2000).

The notion that "nature must pay its way" has resulted in all things green being big business in mainstream models of economic growth for decades and the largely hegemonic neoliberal, growth-focused and technocentric definitions of the green economy often suggests the re-emergence of familiar colonial power-relations (Howe 2014, Argenti and Knight 2015). The appropriation of land and resources for food or fuel under the banner of sustainability and environmentalism has been termed "green grabbing", where "green" credentials are a façade for exploitative extractive practices. For instance, as Nicolas Argenti and I (2015:782) have argued for renewable energy developments in Greece, "the fact that wind and solar power are renewable, inexhaustible resources might seem to make it impossible for them to be plundered in the way that finite resources such as timber or oil might be, but this is not how things are perceived in Greece today, where renewable energy projects are coming to be seen as new forms of extractive economy, harnessing local natural resources for the benefit of foreign corporations". In other words, a whole multitude of sins can be kept from the public imagination when strategically packaged as 'green'. In green grabbing, environmental agendas are the core drivers and goals of grabs - whether linked to biodiversity conservation, biocarbon sequestration, biofuels, ecosystem services, ecotourism or "offsets" related to any and all of these (Leach 2012). Green grabbing is a rapidly growing part of the green economy's dark side, Melissa Leach (2012) notes, where "ecosystems stand to be 'asset-stripped' for profit and dispossession and further poverty amongst already-poor land and resource users is all too likely". If sustainable development continues to be promoted through existing market-based systems then it is imperative to give more emphasis to an agenda of asset distribution and social justice achieved through drastically improved processes of local consultation, transparency and informed consent.

\section{Promoting Renewables in Greece}

Since 2011 there has been a surge in renewable energy developments in rural and island Greece but many initiatives have already proved to be unsustainable. It is the case that new employment opportunities and avenues for technological innovation have been created but too often government rhetoric on green growth has not been supported by grassroots infrastructure or consultation (on austerity and infrastructure see Bear, this issue). For instance, the three-tier programme to make Greece a leader in solar energy generation by encouraging photovoltaic panels to be placed on private homes for self-sufficiency as well as agricultural land and large-scale solar parks generating energy for international export has fallen into the usual traps of market capitalism. Since the launch of the renewables drives, energy projects faced one major problem, namely liquidity, and it was hoped that the private sector would come to the rescue. Such projects have indeed attracted the attention of European companies and governments who have voiced interest in importing renewable energy from Greece as a means of meeting their own renewable energy generation targets. Here I wish to look at the solar energy case in more detail. 
Within the context of the severe social consequences of seven years of fiscal austerity resulting from a $€ 320$ billion international bailout plan, I have worked with agriculturalists installing photovoltaic panels on their land on the plain of western Thessaly in central Greece. Many feel that they are being asked to make a choice between a stable monthly income offered by seemingly generous feed-in tariffs and lease agreements or potential economic destitution. For farmers, the average monthly income from signing twenty-five year contracts to, as they say, "grow photovoltaics" and sell solar energy to the provider is currently greater than the revenue from crop production, yet the average loan required for a typical $100 \mathrm{~kW} / \mathrm{h}$ photovoltaic development on agricultural land is $€ 180,000$. Loans are advertised as returnable over twenty-five years with repayments automatically deducted from the monthly income provided by the panels. In central Greece, farmers refer to new photovoltaic parks as a foreign invasion, ravishing the most fertile farmland in Greece for the benefit of multinational investors and bureaucrats in northern Europe. iv In June 2013 the Greek New Democracy government announced a 44.7 percent cut in the feed-in tariff and stopped issuing building permits for photovoltaic developments later that year. The subsidies for feed-in tariffs had dried up. The solar drive has since been 'frozen', often leaving hundreds of thousands of euros-worth of technology and equipment lying dormant on the plains, still unconnected to the grid. ${ }^{v}$

From the prospective of small-scale entrepreneurs, the programme offered substantial business opportunities. With around 25 percent unemployment across all sectors, employment diversification is both commonplace and necessary. Trained mechanics, electricians and technicians took jobs associated with photovoltaic installation. Photovoltaic systems are perceived as relatively simple to install and require minimal extra training for people with a background in electronics and engineering. Courses offering certificates in correct installation practice are available from local colleges, but these are not necessary and rarely completed. Professionals from unrelated fields became involved in photovoltaic installation including car mechanics, electricians, structural engineers, kitchen salesmen and civil servants. In an era of severe austerity, employment diversification opportunities were most welcome.

The new line in 'second jobs' extended to private businesses importing and installing photovoltaic panels and agencies dealing exclusively in preparing the significant paperwork and negotiating the complex bureaucratic channels involved with securing contracts (Knight and Bell 2013, Knight 2015b). Another line employed surveyors and architects who assessed the plausibility for photovoltaic developments on particular land or buildings. In 2012 in the town of Trikala alone there were fifteen private companies dedicated to importing and installing photovoltaic panels. Some small businesses were subsidiaries of larger companies on the Greek stock market, whilst others floated themselves. In one example of diversification into the green economy, a kitchen salesman named Giorgos established a prosperous photovoltaic company in Kalampaka. He dedicated a floor of his showroom and a substantial garage to his new business. With a team of technicians, he imported and installed solar panels in homes and fields throughout western Thessaly. He set up the business in 2008 after identifying a rising demand for renewable energy technology in the region. In 2012, Giorgos emphasised that the demand for photovoltaics had never been greater owing to a combination of factors, including a decrease in the cost of installation, 
the gradually decreasing feed-in tariffs making people invest whilst the programme was still profitable, a rise in awareness of the programme and a substantial feeling that this was the only way to gain a stable income during times of austerity. Even at a time of growth in the sector, private business owners acknowledged that their enterprise was in all probability temporary; Giorgos said that "in five years, maximum, I will not have this business. The green energy bubble will burst". He cited a lack of government support, limited consultation 'on the ground' with local farmers, the absence of special training for bureaucrats at the regional level dealing with energy programmes, and what he termed "the definite corruption of people in power siphoning-off money into their own pockets". Giorgos knew that his enterprise was opportunistic and his prophecies held much truth; in 2014 he went out of business.

Stories of hope followed by pain extend to the local offices of Greece's main energy supplier, DEl. When I visited in 2012 there was an air of optimism about the future of the green economy and the new job opportunities that might be created in one of the few expanding markets. The director, a moustached gentleman in his mid-fifties named Apostolis, voiced his concerns about German companies "circling like sharks" ready to divide-up and sell-off DEI piece-by-piece and claimed that the fate of the company lay in the success or otherwise of the renewables initiative. During my following periodic visits the tone of conversation has rapidly grown more sombre. In autumn 2016 job and wage cuts were being implemented, something the director put down to the freezing of the renewables programme which he claimed was due to corruption in government and a lack of knowledge transfer at the grassroots level. Apostolis passionately expressed his belief that the initiative was "nonsense" and "empty", a façade to win votes and a short-term policy that had failed to reach its immense potential because it had been used as a political tool both by the EU and in Greece. Apostolis had recently been forced to release three members of staff and reduce most full-time employees to part-time contracts. He was only allowed to use his company car on two days a week to save on fuel bills. The agriculturalists too, he said, had been "cheated" by exaggerated promises of future sustainability when the programme "was never suitable, not even really meant to help them".

The green economy that was supposed to save Greece has, among my research participants, been primarily viewed as an extractive programme of neoliberal exploitation and ecodegradation. The solar project has evoked discourses of international conspiracy and interference, of foreign tutelage and intervention, and of national backwardness, disgrace, and humiliation (Knight and Argenti 2015). Harnessing renewable energy raises paradoxes about resource ownership, national sovereignty, and the shifting geopolitical boundaries of international "energopower" (Boyer 2014). For the government officials I interviewed at the Regulatory Authority for Energy and at the Ministry of Environment, Energy, and Climate Change, and for the local politicians and councillors deciding on the solar projects there is little option but to follow the path of renewable energy investment that actually helps to maintain the fundamental structures of neoliberalism that led to the current economic crisis - short-term projects of accumulation, exploitation of local and national resources to serve big business and corporate opportunism driven by market economics. Green though their cladding might be, the interventionist policies and privatization drives emerging in crisisridden Greece appear to be projects of green grabbing akin to those prominent in the Global South. Many of my research participants believe that the Greek government is proposing 
that the state become a 'rent collector', surviving on the extractive resource rents, taxes, and royalties paid by transnational companies while being exploited as part of the new Global South.

\section{Conclusion}

The green economy has great potential as an alternative to austerity politics in Greece and elsewhere in Europe. Yet, the priorities of European Union policymakers, in particular, continue to focus on what they believe to be complementary poles of market liberalisation and climate protection; EU, World Bank and IMF policy discourse asserts that liberalisation and market competition are the pre-requisites for an energy transition to a low-carbon future (Sweeney 2015:4). This neoliberal approach to the green economy seems to be failing across Europe, reinforcing social inequalities and serving the interests of multinationals instead of truly investing in a sustainable transition to new forms of energy production and environmental protection. One major concern of my research participants has been the lack of grassroots engagement; rarely have there been local consultation or public relations events about the programme of alternative energy, leading to a scattered distribution of photovoltaic parks in western Thessaly and an abundance of myths about the initiative, including the rumour that environmentally harmful new composite panels are being trialled in the area. Neither has there been an attempt to inform administrators in local government about the details of the project - in one major town the councillor responsible for EU programmes for agriculturalists claims that he gets his information from the farmers themselves and has not "spoken to Athens" for many years. There has been a general breakdown in systems of bureaucratic communication and information distribution, but this is hardly surprising in a country already on its knees.

Contrary to views that cast 'crisis' as an incubator of economic strategies that may feed green ecological transformations of the economy leading, ultimately, to sustainable growth, multinational corporations in the green economy sector have taken advantage of austerity policy to pursue neoliberal business practices that benefit investors and bureaucrats in northern Europe while depleting local livelihoods. Current configurations of advanced capitalist power enable and promote injurious "green grabbing" in part by leveraging the fantasy of a green growth economy as a solution to the fiscal crisis.

Although staggeringly off-mark in suggesting that environment, society and economy are not linked or discussed almost interchangeably in Greece today, Alexis Tsipras was correct in saying that elites and existing structures of economic power do not give up their privileges willingly. Projects that encourage investment in green futures need to be re-designed to put human, societal, ethical and environmental needs before private profit. This may take the form of energy democracy or smaller-scale community-led energy initiatives that are decentralised from government control. The small-scale photovoltaic developments placed on private homes in Greece have, for instance, been very successful in bringing down heating prices for the homeowner and providing a degree of self-sufficiency in energy production. Homeowners report feeling a degree of sovereignty, empowerment and self-determination and say that their optimism has spilt over into other realms of their everyday life. As an alternative to austerity the green economy requires further uncoupling from neoliberal business opportunism. Targeted public expenditure, policy reforms and regulation changes should guide private investment that aims to reduce carbon emission, enhance energy 
efficiency and prevent eco-degradation. Then natural capital can be harnessed as an economic asset for sustainable long-term public good.

\section{Acknowledgements}

I thank Deborah James and Laura Bear for the invitation to the 'Alternatives to Austerity?' workshop held at the LSE in June 2016. For conversations on the green economy I am particularly grateful to Nathalie Ortar and Laura Rival. I thank Gustaaf Houtman and the two anonymous reviewers for their constructive comments. The research is supported by a Leverhulme fellowship ECF-2015-214.

\section{References}

Argenti, Nicolas and Daniel M. Knight. 2015. Sun, Wind, and the Rebirth of Extractive Economies: Renewable Energy Investment and Metanarratives of the Crisis in Greece. Journal of the Royal Anthropological Institute 21(4):781-802.

Boyer, Dominic. 2014. Energopower: An Introduction. Anthropological Quarterly 87(2):309334.

Fairhead, James., Leach, Melissa., and Ian Scoones. 2012. Green Grabbing: a new appropriation of nature?, The Journal of Peasant Studies 39(2):237-261.

Howe, Cymene. 2014. Anthropocenic Ecoauthority: The Winds of Oaxaca. Anthropological Quarterly 87(2):381-404.

Kirksey, Eben. 2015. Emergent Ecologies. Durham: Duke University Press.

Knight, Daniel M. 2015a. History, Time, and Economic Crisis in Central Greece. New York: Palgrave Macmillan.

Knight, Daniel M. 2015b. Opportunism and Diversification: Entrepreneurship and Livelihood Strategies in Uncertain Times. Ethnos: Journal of Anthropology 80(1): 117-144.

Knight, Daniel M. 2017. Energy Talk, Temporality, and Belonging in Austerity Greece. Anthropological Quarterly 90(1):159-184.

Knight, Daniel M. and Sandra Bell. 2013. Pandora's Box: Photovoltaic Energy and Economic Crisis in Greece. American Institute of Physics Journal of Renewable and Sustainable Energy 5:1-16.

Leach, Melissa. 2012. The dark side of the green economy: 'Green grabbing'. Al Jazeera, 20th June $2012 \quad$ (accessed $1^{\text {st }}$ January 2017) http://www.aljazeera.com/indepth/opinion/2012/06/201261885431273708.html

Mol, Arthur. and Gert Spaargarden. 2000. Ecological modernisation theory in debate: a review. Environmental Politics 9(1):17-49. 
Sweeney, Sean. 2015. Energy Democracy in Greece: SYRIZA's Program and the Transition to Renewable Power. Trade Unions for Energy Democracy, Working Paper Number 3, Cornell Univeristy.

\footnotetext{
' http://www.lse.ac.uk/websitearchive/newsAndMedia/videoAndAudio/channels/publicLecturesAndEvents/player.aspx?id=1837 ii "The political resolution of the 1st congress of SYRIZA SYRIZA and the great social and political movement of subversion." LEFT.gr. left.gr, 05 Aug 2013. Web. 16 Dec. 2013. <http://left.gr/news/political-resolution-1stcongress-syriza>.

iii www.unep.org/greeneconomy

iv It is commonly understood that Dimosia Epicheirisi llektrismou (DEI) directly purchases the photovoltaic energy. However, DEI, a public company traded on the Greek stock exchange with the Greek state as its major shareholder, owns LAGIE SA (Litourgos Agoras Ilektriks Energias AE), a non-profit organisation that represents the interests of European Energy Stock Exchanges that operate the wholesale markets of electric energy, natural gas and pollution rights. LAGIE implements mechanisms of environmental and energy policies within the context of the planning objectives of the European legal framework (http://www.lagie.gr/etaireia/skoposarmodiotites/). DEI purchases the energy through LAGIE at a fixed 25year price.

v The Regulatory Authority for Energy in Greece reports that there were 257,002 disconnections because of nonpayment of bills in the first nine months of 2014 alone. Also in 2014, Greece had the second highest number per capita of electricity and gas disconnections in the EU, behind only Portugal (Sweeney 2015).
} 